\title{
mHealth and Health Care Service Delivery in Africa: A Systematic Review
}

\author{
Austin Eze Egede ${ }^{1}$, Cajetan Ikechukwu Ilo ${ }^{2}$, Maryjane Ikechukwu-Nwobodo ${ }^{3}$, Tessy Amaka Nnaji ${ }^{4}$, \\ Rita Ihuoma Anaba ${ }^{4}$, Ignatius Obilor Nwimo ${ }^{2}$, Nwamaka A. Elom ${ }^{2}$, Uchechukwu A. Ezugwu, \\ Lazarus Eneje Ezugwu ${ }^{6}$ \& Ifeanyi Jude Nkwoka ${ }^{7}$ \\ ${ }^{1}$ African Institute for Health Policy \& Health Systems, Ebonyi State University, Abakaliki, Nigeria \\ ${ }^{2}$ Department of Human Kinetics and Health Education, Ebonyi State University, Abakaliki, Ebonyi State, Nigeria \\ ${ }^{3}$ Ebonyi State Ministry of Health, Abakaliki, Nigeria \\ ${ }^{4}$ Department of Paediatrics, Alex-Ekwueme Federal Teaching Hospital, Abakaliki, Nigeria \\ ${ }^{5}$ Department of Medical Rehabilitation, University of Nigeria, Enugu Campus, Nigeria \\ ${ }^{6}$ Enugu State College of Health Technology, Oji-River, Nigeria \\ ${ }^{7}$ Community Health Usmanu Dan Fodiyo, University Sokoto, Nigeria \\ Correspondence: Dr Cajetan Ikechukwu Ilo, Department of Human Kinetics and Health Education, Ebonyi State \\ University, Abakaliki, Nigeria. Tel: 234-803-343-0522.
}

Received: September 26, 2020 Accepted: January 7, 2021 Online Published: January 21, 2021

doi:10.5539/gjhs.v13n2p123 URL: https://doi.org/10.5539/gjhs.v13n2p123

\begin{abstract}
We conducted a systematic review of studies on mHealth and health care services delivery that were carried out within Africa. Our search process was through MEDLINE, and then on PubMed, we searched key terms based on various keywords: "Whatsapp, health, Africa, Text messages, health impact, Africa, mHealth tools, Africa". This was done in December of 2018. Only English written articles from journals indexed in Science Citation Index Expanded and Social Science Citation Index were incorporated in this review. In line with our inclusion criteria, only a total of 19 out of 155 studies were relevant. Inferences from these studies showed that mHealth tools are speedy and quality means for health care delivery in Africa. We also found out that there is less usage of internet devices in Africa as suspected. There is a serious need for improvement in the use of other online based mHealth tools as it was found that the use of Short Messaging Service (SMS) has been the nearly the sole mHealth intervention utilized in Africa. This, it is believed would foster better wider intervention and implementation of quality health outcomes in Africa, and other low and middle-income regions of the world.
\end{abstract}

Keywords: Africa, mhealth, whatsapp, text messages, health care

\section{Introduction}

Two quick submissions:

“The African communications 'revolution' has been remarkable: by the end of 2013, mobile phone penetration rates were estimated to have reached $80 \%$, and a recent World Bank report (2014) noted that more Africans now have a mobile phone than have a toilet. Although only $11 \%$ of phones in Sub-Saharan Africa currently have fast internet access $(3 \mathrm{G})$, this proportion is rising rapidly as costs fall and demand increases" (Hampshire et al., 2015:1).

"Sub-Saharan Africa is seeing an accelerating migration to mobile broadband capable connections. The next couple of years are a key tipping point as $2 \mathrm{G}$ connections become a minority of the region's total connections base. $3 \mathrm{G}$ will emerge as the dominant technology in the region over the next few years, accounting for $60 \%$ of Sub-Saharan Africa's connections by the end of 2025. GSMA Intelligence forecasts the first commercial 5G services to be launched in the region by 2021 , with $5 \mathrm{G}$ connections accounting for $2.6 \%$ of the total connections base by 2025" (GSMA, 2018: 3).

The above statement clearly places Sub-Saharan Africa and the globe in both a current and historical perspective. 
The use of technology in enabling speedy and quality access to healthcare services has always been sought after; this means of healthcare delivery bridge the gap within a wide array of healthcare needs faced by the society (Badawy et al., 2016; Badawy et al., 2017; Alquran et al., 2018). These needs could range from dissemination of health information at one end (Pandey et al., 2013; Giodarno et al., 2014), to the performance very complex medical procedures and surgeries at the other extreme (Surka et al., 2014). The use of technology in health has taken various forms like telehealth, telemedicine, eHealth and mHealth (Gustafson et al., 2012; Otu et al., 2016; Andres et al., 2018; Douglas et al., 2018). It should be noted that these all mean different things. While telemedicine and telehealth focus on both exclusive clinical and all-encompassing involvement in healthcare delivery respectively, eHealth and mHealth refer to wide electronic health management and mobile phone/tablet based management of health respectively (Malvey \& Slovensky, 2014). Also, due to the ease of the use and the supposed associated low cost of mHealth, it has gained greater prominence over other forms, especially in Africa (WHO, 2018). MHealth is also supposed to use a wide range of services which one's mobile phone/operator can easily offer, especially where there is a relative ease of mobile phone penetration, and a large percentage of the society being underserved on the basis of healthcare provision, as could be seen in most African Nations (Bagayoko et al., 2014). Critical health policy stakeholders at the macro, meso, and micro levels seem to have adopted mHealth in dealing with health issues affecting Sub-Saharan Africa (Little et al., 2013; Githinji et al., 2014; Stanton et al., 2015; WHO, 2018), and this concept has gained a lot of attention due to the obvious belief that the number of mobile devices has grown exponentially in the region (GSMA, 2018).

The use of mHealth technology in healthcare- related activities have gained global attention and has increased access to quality health services (Betjeman et al., 2013; S. Davey \& A. Davey, 2014). This has impacted positively on the World Health Organization's six building blocks of health systems, especially on technology and service delivery domains. The operationalization of mHealth is helping to address the barriers to access to health services and the uptake of critical public health interventions in no small measure (S. Davey \& A. Davey, 2014). According to Davey and Colleague, developed countries contribute more than three-quarter of the over seven billion mobile phone subscription in the world (S. Davey \& A. Davey, 2014).

It is also worth stating that, of all the other technological based support systems for health, mHealth remains the cheapest in assessing hard to reach areas (WHO, 2011; Davey et al., 2014); making it much more sought after as an intervention tool in a region with multiple low and middle-income countries (UN Foundation, 2009). In light of the fact that mHealth is of dual nature-online, especially using smartphones applications, and offline, using text messages and USSD (Unstructured Supplementary Service Data), it is troubling that the focus of mHealth may be bias and skewed towards the use of mainly offline services, denying the populace comprehensive access to the expected benefits of mHealth. This is so because, both Hampshire et al. (2015) and GSMA (2018) describe a very bleak state of internet infrastructure, that is, assuming one was to even downplay the fact that the subscription for constant and high-quality internet services, although unjustified, is a luxury in Africa (see Figure 1). The figure 1 below clearly shows that while the Gross National Income (GNI) Per Capital (P.C) expended on mobile phone internet subscriptions of all global sub-regions have been on the decline, Africa still stands out as being most expensive, even when mobile phone penetration is on the increase.

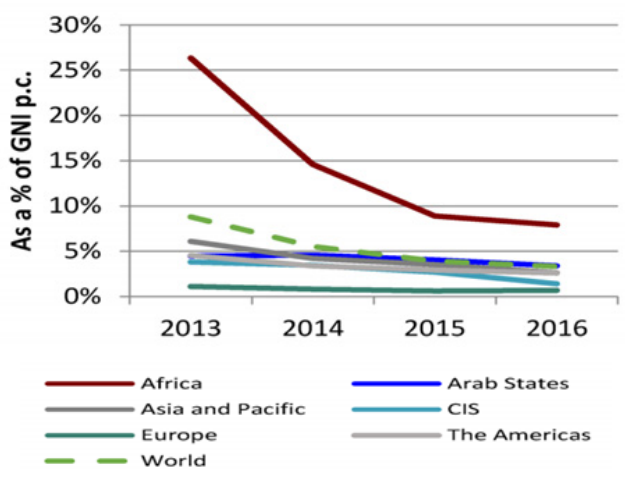

Figure 1. Cost of mobile-based internet subscription-

*CIS (Commonwealth of Independent States)

Source: International Telecommunication Union. (2017) ICT PRICES 2017. Geneva. Retrieved from 
https://www.itu.int/dms_pub/itu-d/opb/ind/D-IND-ICT_PRICES.01-2017-PDF-E.pdf

and https://www.itu.int/en/ITU-D/Statistics/Documents/statistics/2018/ITU_Key_2005-2018_ICT_data_with\%20LD Cs_rev27Nov2018.xls

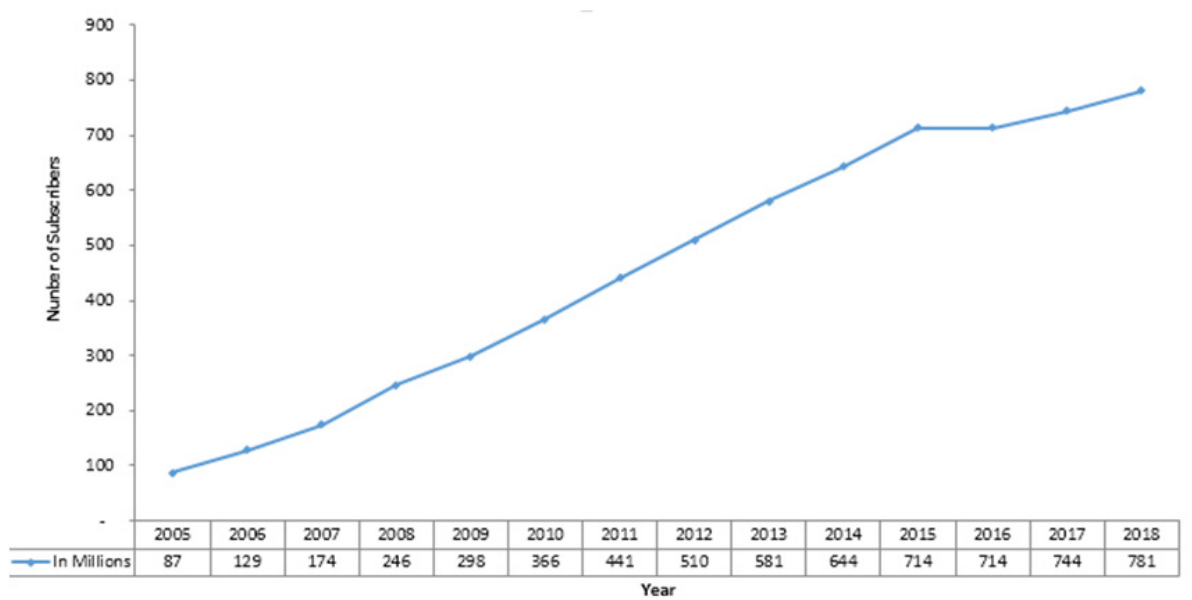

Figure 2. Mobile-cellular telephone subscriptions in Africa

Source: (Lee, Cho, \& Kim, 2017; Ronquillo \& Currie, 2010; International Telecommunication Union, 2017)

This review focuses on the two prongs of mHealth, one-online, and the other-offline. For the online tool, a review on the use of 'WhatsApp' mobile phone application has been carried out, while for the offline, we restrict our search to 'text messages'. The choice of this scope is borne out of the fact that policy recommendations should be contextualized to suite the several low and middle-income countries in Africa. While there are a plethora of mHealth tools, like Facebook, Instagram, Weibo, Telegram, Twitter, Snapchat, Vimeo, Viber amongst others, WhatsApp has been known to address issues of health with relatively low cost and wider reach (WHO, 2011; Giodarno et al., 2014; Pentapati et al., 2015; Khanna et al., 2015; Johnston et al., 2015; Boulos et al., 2016). Text messages, on the other hand, are also low cost, and while it may not be the only offline based mhealth tool, it has been well used as an intervention (WHO, 2018).

\section{Methods}

The Preferred Reporting Items for a Systematic Review and Meta-analysis checklist protocol was used for the review (Mother et al., 2015)

\subsection{Search Strategies}

Systematic reviews of published quantitative literatures were conducted. The searches were conducted following an adaptation of Pubmed and Google Scholar databases. Additional search was done using Snowballing method. The search was carried out on December 2018. The following search terms were used: "Whatsapp", "health", "Africa”, "Text” “messages”, "health”, "impact”, "mHealth”, "tools”.

\subsection{Inclusion Criteria}

Only intervention studies published in English and conducted in Africa were eligible for inclusion. Studies published between 2010 and 2018 were included in the review. Also included in the review were articles published in highly ranked journals indexed by Science Citation Expanded/Social Science Citation Index. More so, only empirical studies that discuss the relationship between mHealth and health care service delivery were included in the review. This was to ensure that our results were evidence-informed.

\subsection{Exclusion Criteria}

Non-intervention articles and studies conducted outside Africa were excluded. Also excluded from the review were studies published in other languages other than English language.

\subsection{Data Extraction}

A data extraction form developed by us was used for the review. Included articles were exported to Mendeley 
reference manager to keep take track of the references. The following domains were included in the data extraction form: Author and year of publication, Country, Information tool, Health issue/samle, Impact assessed, Types of study, Intervention used, and Policy Implication

\subsection{Evidence Generation Method}

For the evidence we utilized in this review, we adopted a systematic search in December 2018, this search was performed thus; first, using MEDLINE, and we narrowed our search to PubMed. Our search fell into three major categories/keywords:

\section{Category 1: "Whatsapp, health, Africa" = 20 Publications;}

\section{Category 2: "Text messages, health impact, Africa" = 65 Publications;}

\section{Category 3: " $m$ Health tools, Africa" $=70$ Publications.}

We also performed a Snow-balling exercise that enabled us to manually select the work of Lester et al., (2010). Furthermore, although not through the conventional manual perusal of the references of a study, during the search protocols of the various search terms, four (4) other studies (Greishman et al., 2014; Ha et al., 2016; Haricharan et al., 2017; Kop et al., 2018) were added to the pool of articles we reviewed. These were seen at the "similar articles" and "cited by PubMed central articles" section, and were scrutinized on the basis of strict inclusion rules as having been stated above.

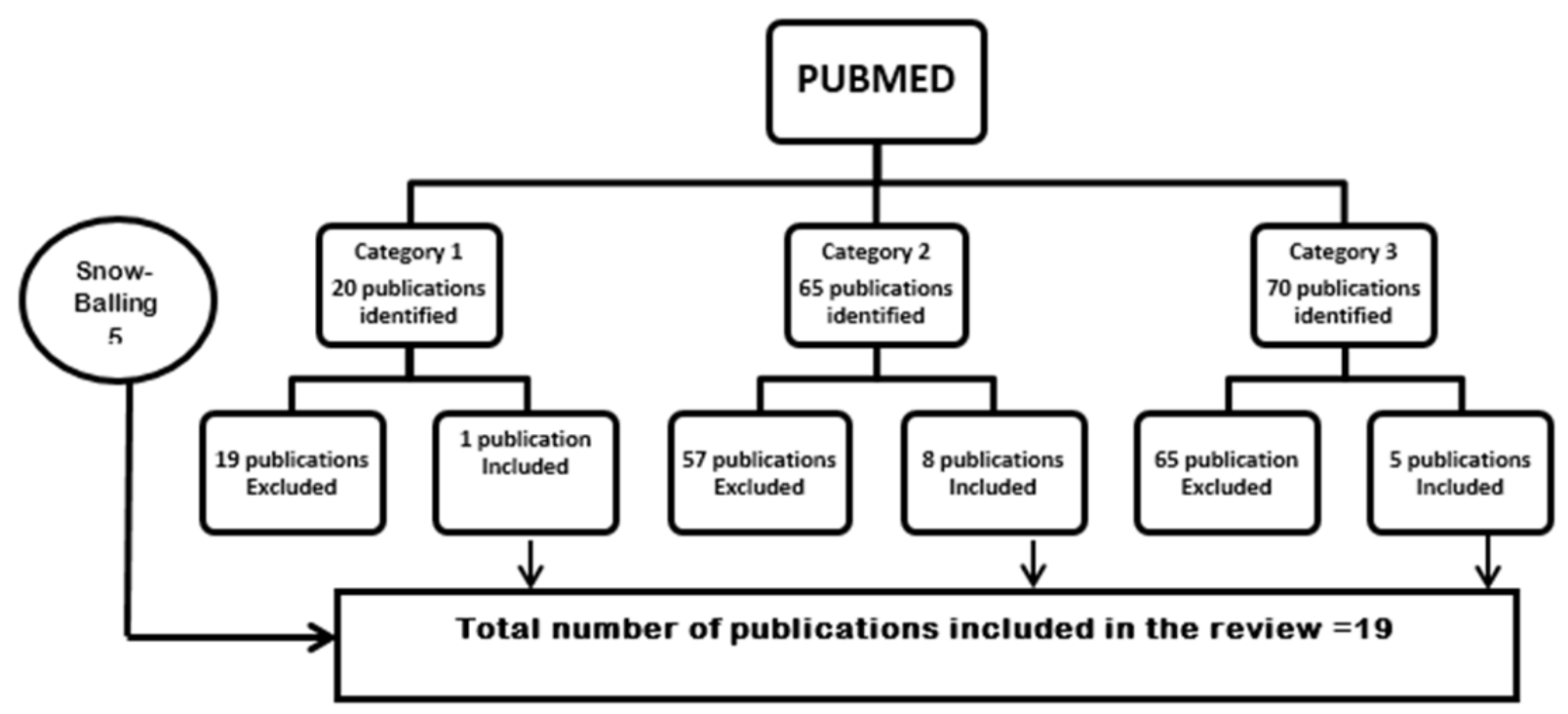

Figure 3. Method Design

Flow chart showing detailed article extraction and evaluation method (Uneke et al., 2016; Okedo-alex et al., 2019; Onwujekwe et al., 2019). 
Table 1. Study characteristics of articles reviewed

\begin{tabular}{|c|c|c|c|c|c|c|c|}
\hline $\begin{array}{l}\text { Authors and Year of } \\
\text { Publication }\end{array}$ & Country & Information Tool & Health Issue/Sample & Impact Assessed & Types of Study & $\begin{array}{l}\text { Internet } \\
\text { Use }\end{array}$ & Policy Implication \\
\hline Pimmer et al. 2017 & Malawi & WhatsApp & $\begin{array}{l}\text { Mobile rinstant } \\
\text { messaging for rural } \\
\text { health workers }\end{array}$ & $\begin{array}{l}\text { Enhanced ease of } \\
\text { connectedness. }\end{array}$ & Survey & Yes & $\begin{array}{l}\text { WhatsApp can close the gap } \\
\text { between patients \& } \\
\text { clinicians }\end{array}$ \\
\hline Greisman et al. 2014 & Uganda & $\begin{array}{l}\text { Smartphone-based } \\
\text { teledermatology } \\
\text { consult services }\end{array}$ & $\begin{array}{l}\text { Tele-dermatology } \\
\text { among } \quad \text { Medical } \\
\text { students }\end{array}$ & $\begin{array}{l}\text { Smartphone-based } \\
\text { systems are feasible for } \\
\text { delivery of cases }\end{array}$ & Evaluation & No & $\begin{array}{l}\text { Smartphone-based } \\
\text { teledermatology is cost } \\
\text { effective }\end{array}$ \\
\hline Ha et al. 2016 & Botswana & $\begin{array}{l}\text { Mobile phone or tablet } \\
\text { app and online } \\
\text { database }\end{array}$ & $\begin{array}{l}\text { Time Assessment of in } \\
\text { completing TB contact }\end{array}$ & $\begin{array}{l}\text { Mobile Health approach } \\
\text { reduce completion time }\end{array}$ & Evaluation & No & $\begin{array}{l}\text { mHealth is beneficial for } \\
\text { tracking TB }\end{array}$ \\
\hline Georgette et al. 2017 & $\begin{array}{l}\text { South } \\
\text { Africa }\end{array}$ & SMS & $\begin{array}{l}\text { Weekly use of SMS for } \\
\text { Anti-Retroviral } \\
\text { Therapy }\end{array}$ & $\begin{array}{l}\text { Small measurable clinical } \\
\text { impact }\end{array}$ & $\begin{array}{l}\text { Retrospective } \\
\text { cohort study }\end{array}$ & No & $\begin{array}{l}\text { SMS is effective in } \\
\text { enhancing enrollment }\end{array}$ \\
\hline $\begin{array}{l}\text { Finocchario-Keder } \\
\text { et al. } 2014\end{array}$ & Kenya & $\begin{array}{l}\text { HIV infant tracking } \\
\text { system (HIT system) }\end{array}$ & $\begin{array}{l}\text { Evaluation of the } \\
\text { impact of HCT for } \\
\text { quality }\end{array}$ & $\begin{array}{l}\text { A significant increase in } \\
\text { the proportion of } \\
\text { HIV-infected infants that } \\
\text { started ART. }\end{array}$ & $\begin{array}{l}\text { Before-and-After } \\
\text { study }\end{array}$ & No & $\begin{array}{l}\text { HIT system can improve the } \\
\text { quality and efficiency of } \\
\text { HIV care }\end{array}$ \\
\hline Haberer et al 2016 & Uganda & SMS reminder & $\begin{array}{l}\text { Exploring the effects of } \\
\text { SMS plus real-time } \\
\text { adherence }\end{array}$ & $\begin{array}{l}\text { SMS increased adherence } \\
\text { in initiating ART }\end{array}$ & $\begin{array}{l}\text { Randomized } \\
\text { control trial }\end{array}$ & No & $\begin{array}{l}\text { Implementation of SMS can } \\
\text { enhance ART adherence }\end{array}$ \\
\hline Lester, et al. 2010 & Kenya & SMS & $\begin{array}{lr}\text { Assessment of mobile } \\
\text { communication } & \text { in } \\
\text { starting } & \text { ART } \\
\text { adherence. } & \end{array}$ & $\begin{array}{l}\text { Adherence improved with } \\
\text { weekly SMS reminders }\end{array}$ & $\begin{array}{l}\text { Randomized } \\
\text { clinical trial }\end{array}$ & No & $\begin{array}{l}\text { SMS support can } \\
\text { significantly improve drug } \\
\text { adherence. }\end{array}$ \\
\hline $\begin{array}{l}\text { Haricharan, et al. } \\
2017\end{array}$ & $\begin{array}{l}\text { South } \\
\text { Africa }\end{array}$ & SMS & $\begin{array}{l}\text { Assessment of } \\
\text { SMS-based campaign }\end{array}$ & $\begin{array}{l}\text { SMS improved Deaf } \\
\text { people's knowledge of } \\
\text { hypertension }\end{array}$ & $\begin{array}{l}\text { Pre-test } \quad- \\
\text { post-test survey }\end{array}$ & No & $\begin{array}{l}\text { SMSs can be effective } \\
\text { knowledge }\end{array}$ \\
\hline Kop, et al. 2018 & Kenya & SMS & $\begin{array}{lr}\text { Weekly } & \text { SMS } \\
\text { intervention } & \text { in } \\
\text { retention } & \end{array}$ & No improved retention & $\begin{array}{l}\text { Randomized } \\
\text { Parallel-group } \\
\text { study }\end{array}$ & No & $\begin{array}{l}\text { SMS has a role in improving } \\
\text { self-perceived health quality }\end{array}$ \\
\hline Liu et al. 2016. & Nigeria & $\begin{array}{ll}\text { SMS } & \text { reminder } \\
\text { messages } & \end{array}$ & $\begin{array}{l}\text { Evaluation of SMS } \\
\text { reminder messages for } \\
\text { treatment adherence }\end{array}$ & $\begin{array}{l}\text { SMS reminder increased } \\
\text { treatment adherence }\end{array}$ & Survey & No & $\begin{array}{l}\text { Implementation of policy on } \\
\text { text message can be effective } \\
\text { for treatment adherence. }\end{array}$ \\
\hline
\end{tabular}


Table 1. Cont'd

\begin{tabular}{|c|c|c|c|c|c|c|c|}
\hline $\begin{array}{l}\text { Authors and Year of } \\
\text { Publication }\end{array}$ & Country & Information Tool & Health Issue/Sample & Impact Assessed & Types of Study & $\begin{array}{l}\text { Internet } \\
\text { Use }\end{array}$ & Policy Implication \\
\hline $\begin{array}{l}\text { Mushamiri et al. } \\
2015\end{array}$ & Kenya & SMS & $\begin{array}{l}\text { End-User changes } \\
\text { health-seeking behavior }\end{array}$ & $\begin{array}{l}\text { mHealth tool } \\
\text { strengthened adherence } \\
\text { to ANC }\end{array}$ & Evaluation & No & $\begin{array}{l}\text { Incorporating mHealth tools in } \\
\text { CHW programs can improve } \\
\text { adherence to ANC and enhance } \\
\text { PMTCT efforts }\end{array}$ \\
\hline Rokicki, et al. 2017 & Ghana & Mobile phone quiz & $\begin{array}{l}\text { Assessment of the degree to } \\
\text { which mHealth programs reach } \\
\text { target adolescent }\end{array}$ & $\begin{array}{lr}\text { Increased } & \text { SRH } \\
\text { knowledge } & \text { among } \\
\text { adolescent girls } & \\
\end{array}$ & $\begin{array}{l}\text { Case-control } \\
\text { survey. }\end{array}$ & No & $\begin{array}{l}\text { Mobile phone quiz has the potential } \\
\text { of increasing adolescents } \\
\text { knowledge }\end{array}$ \\
\hline Jian, et al. 2012 & Swaziland & SMS & $\begin{array}{l}\text { Using SMS to reduce } \\
\text { Turnaround Time (TAT) }\end{array}$ & $\begin{array}{l}\text { Improved TAT with } \\
\text { SMS than paper-based }\end{array}$ & Implementation & No & $\begin{array}{l}\text { SMS based reporting of lab results } \\
\text { has prospect for reducing TAT }\end{array}$ \\
\hline $\begin{array}{l}\text { Friedman, et al. } \\
2014\end{array}$ & Ghana & SMS & $\begin{array}{l}\text { Information management of } \\
\text { childhood diarrhoea }\end{array}$ & $\begin{array}{l}\text { Improved provider's } \\
\text { reported compliance } \\
\text { with WHO standards. }\end{array}$ & $\begin{array}{l}\text { Mystery client } \\
\text { survey. }\end{array}$ & No & $\begin{array}{l}\text { SMS is effective in providing } \\
\text { information that is capable of } \\
\text { changing the health provider's } \\
\text { behaviors. }\end{array}$ \\
\hline $\begin{array}{l}\text { Armstrong, et al. } \\
2011\end{array}$ & Botswana & SMS & $\begin{array}{l}\text { Evaluation of SMS for clinical } \\
\text { guidelines }\end{array}$ & $\begin{array}{l}\text { The tool enabled query } \\
\text { and review of a } \\
\text { country's specific } \\
\text { clinical guidelines. }\end{array}$ & Pre-use Survey. & No & $\begin{array}{l}\text { This tool can be used on a long-term } \\
\text { basis in areas of limited interne } \\
\text { access }\end{array}$ \\
\hline $\begin{array}{l}\text { Hirsch-Moverman } \\
\text { et al. } 2017\end{array}$ & $\begin{array}{l}\text { South } \\
\text { Africa }\end{array}$ & SMS & $\begin{array}{l}\text { Use of SMS in providing } \\
\text { real-time adherence to patients }\end{array}$ & $\begin{array}{l}\text { SMS was found to be } \\
\text { user-friendly and } \\
\text { accepted by patients }\end{array}$ & $\begin{array}{l}\text { Mixed- methods } \\
\text { implementation } \\
\text { study. }\end{array}$ & No & $\begin{array}{l}\text { SMS can inform adherence and } \\
\text { retention strategies in managing } \\
\text { HIV/TB }\end{array}$ \\
\hline Little et al. 2013 & Ethiopia & $\begin{array}{l}\text { OpenDataKit } \\
\text { platform (ODK) } \\
\text { using the phone }\end{array}$ & $\begin{array}{l}\text { Evaluation of smartphone } \\
\text { technology for delivering health } \\
\text { care services }\end{array}$ & $\begin{array}{l}\text { Ownership and use of } \\
\text { mobile technology } \\
\text { improved the quality of } \\
\text { health care }\end{array}$ & $\begin{array}{l}\text { Observational } \\
\text { Study. }\end{array}$ & Partially & $\begin{array}{l}\text { Technology-driven healthcare can } \\
\text { ensure ownership and } \\
\text { empowerment among health } \\
\text { workers }\end{array}$ \\
\hline Stanton, et al. 2015 & $\begin{array}{l}\text { Ghana, } \\
\text { Malawi }\end{array}$ & SMS & $\begin{array}{l}\text { SMS tools enabled trained } \\
\text { community-based health } \\
\text { workers to report basic } \\
\text { information/Health workers }\end{array}$ & $\begin{array}{l}\text { The tool enabled health } \\
\text { workers to monitor the } \\
\text { community impact of } \\
\text { the SMS efficiently }\end{array}$ & $\begin{array}{l}\text { Case } \\
\text { design. }\end{array}$ & No & $\begin{array}{l}\text { Community-based health worke } \\
\text { are exceptionally well-placed in } \\
\text { quantifying lymphatic filariasis } \\
\text { with the use of mobile phone }\end{array}$ \\
\hline $\begin{array}{l}\text { Shahaurka et al., } \\
2014\end{array}$ & $\begin{array}{l}\text { South } \\
\text { Africa }\end{array}$ & $\begin{array}{l}\text { Paper-based and } \\
\text { mobile phone risk } \\
\text { assessment tool }\end{array}$ & $\begin{array}{l}\text { Evaluation of the use of } \\
\text { mHealth tools in Cardiovascular } \\
\text { Disease (CVD) primary } \\
\text { prevention. }\end{array}$ & $\begin{array}{l}\text { Reduction in CHW } \\
\text { (Community Health } \\
\text { Worker) training time } \\
\text { and risk }\end{array}$ & $\begin{array}{l}\text { A quantitative } \\
\text { and qualitative } \\
\text { study. }\end{array}$ & & $\begin{array}{l}\text { The reduction in } \mathrm{CHW} \text { training time } \\
\text { and lack of error in the calculation } \\
\text { of CVD risk score leading to } \\
\text { adoption and sustainability }\end{array}$ \\
\hline
\end{tabular}




\section{Discussion}

The positive contributions of mHealth tools like SMS, WhatsApp, Instagram, Facebook, and others in healthcare delivery are evident in most countries of the world. These tools cover both offline and online means of communication. However, it was discovered that the majority of mHealth tools utilization in Africa is offline-based (SMS) with less emphasis on online which would have been more efficiently utilized in Africa if internet services were provided and assessed with relative ease. As a matter of fact, only one work actually focused on the use of WhatsApp in health care delivery (Pimmer et al., 20017); which was adjudged as a cheaper and more reliable as it has an end to end encryption needed for privacy in health communication (Boulos et al., 2016). This is one of the evidence to the fact that internet services in Africa which affects its utilization in the healthcare delivery in the continent.

Moreover, this systematic review revealed that the use of mHealth tools in healthcare services focused more on prevention and care of HIV as against other diseases like Pneumonia, Diarrhea, malaria, Tuberculosis etc. The implication is that in Africa, HIV still receives much attention while pneumonia which has overtaken HIV/AIDS as a major killer disease in Africa has received lesser attention (WHO, 2018). This could well mean that healthcare providers, policy makers, and health researchers have not garnered the use of mHealth tools in curbing the menace of these diseases in Africa. It was also observed that the use of mHealth in Africa was majorly directed towards healthcare workers with less consideration of patients and how the tools should assist them with timely access to healthcare services.

Most African countries have not received the much-needed attention on the use of mhealth tools towards ensuring adequate healthcare service delivery; this was evident in the PubMed search conducted which identified the number of intervention which each country received on the use of mHealth tools. Out of the 39 African countries found during the PubMed search, Kenya received the highest number of works (7) that focused on the use of mHealth which is more than any other country. Ghana and South Africa collectively received 4 works each on the issue under discourse; Uganda followed with 3 works. Botswana, Ethiopia, Malawi, and Nigeria have 2 works respectively; while Mali, Swaziland and Tanzania have 1 work respectively. This showed that only 11 countries (representing 20.37\%) out of 54 countries of Africa have received attention on the use of mHealth in healthcare delivery; an indication that mhealth is not positioned on the frontrunner to assist in healthcare delivery in Africa.

\section{Policy Implication}

Premised on the evidence generated from the systematic review, the under listed policy suggestions have been recommended:

It makes sense to say that policy design and implementation on mHealth should be based on evidence, especially in resource-constrained continents such as Africa. As a matter of urgency, African countries, especially the sub-Saharan countries should adopt and implement mHealth interventions in their health systems with the aim of reducing morbidity and mortality, especially among mothers and children, and the immune-compromised groups.

Whereas attention has been focused more on SMS as feasible mHealth intervention tools by numerous recent studies (Lester et al., 2010; Armstrong et al., 2011; Jian et al., 2012; Friedman et al., 2014; Mushamiri et al., 2015; Stanton et al., 2015; Ha et al., 2016; Haberer et al., 2016; Liu et al., 2016; Haricharan et al., 2017; Hirsch-Moverman et al., 2017; Kop et al., 2018), Whatsapp, Instagram, Facebook, LinkedIn tools also have to be exploited equally without bias (Pimmer et al., 2017). Using systems thinking in driving the mHealth intervention, especially in this era where everybody now sees the internet as the most interesting ecological information niche in getting both colloquial and scientific evidence for health care is apt.

Many countries in Africa are still lagging behind on the use of mHealth tools as drivers for achieving the 'Health for All Campaign' as enunciated by the Ama-Alta Declaration in Kazakhstan (WHO, 1978). mHealth tools should be adopted by all African countries because of its communication viability, ease of use, portability, cost-effectiveness, broad access, acceptability, and sustainability.

African countries should as a matter of policy, make a concerted effort towards transiting to higher internet broadband like the $5 \mathrm{G}$ connection, which is in vogue in other more advanced countries of the world at the moment. These concerted efforts must include investments in internet infrastructure, as it has been proven that the internet as a mHealth tool would improve health care service coverage, delivery, intervention, and implementation in Africa (Davey et al., 2014).

There appears to be lacuna for studies that focused on the use of mHealth tools on other diseases like; pneumonia, TB, Malaria, etc. other than the HIV disease. This is as revealed by our PubMed search for empirical works which showed that of the 19 articles reviewed in this study, only a handful were centered outside HIV 
(Finocchario-Kessler et al., 2014; Hirsch-Moverman et al., 2017). This is despite the fact that pneumonia which has its causative agent as Streptococcus pneumonia has been adjudged as the leading cause of childhood death globally, killing about 920000 children per year (Whitney, 2017). mHealth tools should not be used linearly for particular groups of diseases. It is a non-linear reliable tools that can be used to drive any health program effectiveness against any type of disease, be it a communicable disease, none communicable disease or neglected tropical disease of Africa. It is therefore recommended that all the researchers in the Issue Network community should start using mHealth as intervention tools in carrying research on any disease in a bid to reducing morbidity and mortality rate in Africa.

\section{Conclusion}

Despite the records of successes on the use of mHealth in health care delivery in the world, Africa still lags behind other continents of the world. This has largely been attributed to poor access to internet-enabled devices, poor internet services in hard-to-reach settings and general weak health systems. mHealth technology in Africa has rather focused on Short Messaging Services (SMS). Improvement in other aspects of online based mHealth interventions would unarguably scale up the quality and delivery of health care services in Africa.

\section{Acknowledgements}

Not applicable.

\section{Funding}

None.

\section{Ethical Approval and Consent to Participate}

Not applicable.

\section{Author's Contributions}

AEE: conception and study design, data extraction, analysis and interpretation of results, manuscript drafting and approval for final manuscript. CII: study design, data extraction, analysis and interpretation of results, manuscript drafting and approval for final manuscript. MI: study design, data extraction, analysis and interpretation of results, manuscript drafting and approval for final manuscript. TAN: study design, data extraction, analysis and interpretation of results, manuscript drafting and approval for final manuscript. RIA: study design, data extraction, analysis and interpretation of results, manuscript drafting and approval for final manuscript. ION: study design, data extraction, analysis and interpretation of results, manuscript drafting and approval for final manuscript. NAE: study design, data extraction, analysis and interpretation of results, manuscript drafting and approval for final manuscript. UAE: study design, data extraction, analysis and interpretation of results, manuscript drafting and approval for final manuscript. LEE: study design, data extraction, analysis and interpretation of results, manuscript drafting and approval for final manuscript. IJN: study design, data extraction, analysis and interpretation of results, manuscript drafting and approval for final manuscript.

\section{Competing Interests Statement}

The authors declare that there are no competing or potential conflicts of interest.

\section{References}

Alquran, A., Lambert, K. A., Farouque, A., Holland, A., Davies, J., Lampugnani, E. R., \& Erbas, B. (2018). Smartphone applications for encouraging asthma self-management in adolescents: A systematic review. International Journal of Environmental Research and Public Health, 15(2403). 1-11. https://doi.org/10.3390/ijerph15112403

Andrès, E., Talha, S., Zulfiqar, A.A., Hajjam, M., Ervé, S., Hajjam, J., Geny, B., \& El Hassani, A. (2018). Current Research and New Perspectives of Telemedicine in Chronic Heart Failure: Narrative Review and Points of Interest for the Clinician. Journal of Clinical Medicine, 7(544), 1-20. https://doi.org/10.3390/jcm7120544

Armstrong, K., Liu, F., Seymour, A., Mazhani, L., Littman-quinn, R., Fontelo, P., \& Kovarik, C. (2011). Evaluation of txt2MEDLINE and Development of Short Messaging Service-Optimized, Clinical Practice Guidelines in Botswana. Telemedicine and e-Health, 18(1), 14-17. https://doi.org/10.1089/tmj.2011.0014

Badawy, S. M., Thompson, A. A., \& Kuhns, L. M. (2017). Medication Adherence and Technology-Based Interventions for Adolescents with Chronic Health Conditions: A Few Key Considerations. JMIR mHealth and uHealth, 5(12), 1-4. https://doi.org/10.2196/mhealth.8310

Bagayoko, C. O., Traoré, D., Thevoz, L., Diabaté, S., Pecoul, D., Niang, M., Bediang, G., \& Geissbuhler, A. 
(2014). Medical and economic benefits of telehealth in low- and middle-income countries: Results of a study in four district hospitals in Mali. BMC Health Services Research, 14(1), 1-6. https://doi.org/10.1186/1472-6963-14-S1-S9

Bakibinga, P., Kamande, E., Omuya, M., Ziraba, A. K., \& Kyobutungi, C. (2017). The role of a decision-support smartphone application in enhancing community health volunteers' effectiveness to improve maternal and newborn outcomes in Nairobi, Kenya: Quasi-experimental research protocol. BMJ Open, 7(7), 1-10. https://doi.org/10.1136/bmjopen-2016-014896

Boulos, M. N. K., Giustini, D. M., \& Wheeler, S. (2016). Instagram and WhatsApp in Health and Healthcare: An Overview. Future internet, 8(37), 1-14. https://doi.org/10.3390/fi8030037

Davey, S., \& Davey, A. (2014). Mobile- health technology: Can it Strengthen and improve public health systems of other developing countries as per Indian strategies? A systematic review of the literature. International Journal of Medicine and Public Health, 4, 40- 45. https://doi.org/10.4103/2230-8598.127121

Douglas, S., Geiger, E., McGregor, A., Norwich, A., Abbate, D., Hsia, H., \& Narayan, D. (2018). Telehealth in Plastic Surgery. Plastic and Reconstructive Surgery - Global Open, 6(10), 1-5. https://doi.org/10.1097/GOX.0000000000001840

Forenbacher, I., Husnjak, S., Cvitić, I., \& Jovović, I. (2019). Determinants of mobile phone ownership in Nigeria. Telecommunications Policy Journal, 43(October 2018), 1-12. https://doi.org/10.1016/j.telpol.2019.03.001

Finocchario-Kessle, S., Gautney, B. J., Khamadi, S., Okoth, V., Goggin, K., Spinler, J. K., ... \& HITSystem Team. (2014). If you text them, they will come: using the HIV infant tracking system to improve early infant diagnosis quality and retention in Kenya. AIDS, 28(3), 1-16. https://doi.org/10.1097/QAD.0000000000000332

Friedman, W., Woodman, B., \& Chatterji, M. (2015). Can mobile phone messages to drug sellers improve treatment of childhood diarrhoea? A randomized controlled trial in Ghana. Health Policy and Planning, 30(1) 82-92. https://doi.org/10.1093/heapol/czu122

Georgette, N., Siedner, M. J., Petty, C. R., Zanoni, B. C., Carpenter, S., \& Haberer, J. E. (2017). Impact of a clinical program using weekly Short Message Service (SMS) on antiretroviral therapy adherence support in South Africa: a retrospective cohort study. BMC Medical Informatics and Decision Making, 17(18), 1-9. https://doi.org/10.1186/s12911-017-0413-9

Giordano, V., Augusto, H., Henrique, C., Bergamin, A., Serrão, F., Souza, D., \& Pecegueiro, N. (2014). WhatsApp messenger is useful and reproducible in the assessment of tibial plateau fractures: Inter- and intra-observer agreement study. International Journal of Medical Informatics, 2-9. https://doi.org/10.1016/j.jimedinf.2014.11.002

Githinji, S., Kigen, S., Memusi, D., Nyandigisi, A., Wamari, A., Muturi, A., ... \& Zurovac, D. (2014). Using mobile phone text messaging for malaria surveillance in rural Kenya. Malaria Journal, 13(1), 1-9. https://doi.org/10.1186/1475-2875-13-107

Greisman, L., Nguyen, T. M., Mann, R. E., Baganizi, M., Jacobson, M., Paccione, G. A., .. \& Lipoff, J. B. (2014). Tropical medicine rounds: Feasibility and cost of a medical student proxy-based mobile teledermatology consult service with Kisoro, Uganda and Guatemala Lake Atitlan. International Journal of Dermatology, 1-8. https://doi.org/10.1111/ijd.12708

Gustafson, D., Wise, M., Bhattacharya, A., Pulvermacher, A., Shanovich, K., Phillips, B., ... \& Kim, J. S. (2012). The effects of combining web-based eHealth with telephone nurse case management for pediatric asthma control: A randomized controlled trial. Journal of Medical Internet Research, 14(4), 1-19. https://doi.org/10.2196/jmir.1964

Ha, Y. P., Tesfalul, M. A., Littman-quinn, R., Antwi, C., Green, R. S., Mapila, T. O., ... \& Kovarik, C. L. (2018). Evaluation of a Mobile Health Approach to Tuberculosis Contact Tracing in Botswana. Journal of Health Communication. 21(10), 1115-1121. https://doi.org/10.1080/10810730.2016.1222035

Haberer, J. E., Musiimenta, A., Atukunda, E. C., Musinguzi, N., Wyatt, M. A., Ware, N. C., \& Bangsberg, D. R. (2016). Short message service ( SMS ) reminders and real-time adherence monitoring improve antiretroviral $\begin{array}{lllll}\text { therapy adherence in rural Uganda. } & \text { AIDS, 30(8), } & \text { 1295-1299. }\end{array}$ https://doi.org/10.1097/QAD.0000000000001021

Haffey, F., Brady, R. R. W., \& Maxwell, S. (2013). A comparison of the reliability of smartphone apps for opioid 
conversion. Drug Safety, 36(2), 111-117. https://doi.org/10.1007/s40264-013-0015-0

Hampshire, K., Porter, G., Owusu, S. A., Mariwah, S., Abane, A., Robson, E., .. \& Milner, J. (2015). Informal m-health: How are young people using mobile phones to bridge healthcare gaps in Sub-Saharan Africa? Social Science and Medicine, 142, 90-99. https://doi.org/10.1016/j.socscimed.2015.07.033

Haricharan, H. J., Heap, M., Hacking, D., \& Lau, Y. K. (2017). Health promotion via SMS improves hypertension knowledge for deaf South Africans. BMC public Health, 17(663), 1-17. https://doi.org/10.1186/s12889-017-4619-7

Hirsch-Moverman, Y., Daftary, A., Yuengling, K. A., Saito, S., Ntoane, M., Frederix, K., ... \& Howard, A. A. (2017). Using mhealth for HIV/TB treatment support in lesotho: Enhancing patient-provider communication in the START study. Journal of Acquired Immune Deficiency Syndromes, 74, 37-43. https://doi.org/10.1097/QAI.0000000000001202

International Telecommunication Union. (2017). ICT PRICES 2017. Geneva. Retrieved from https://www.itu.int/dms_pub/itu-d/opb/ind/D-IND-ICT_PRICES.01-2017-PDF-E.pdf and https://www.itu.int/en/ITU-D/Statistics/Documents/statistics/2018/ITU_Key_2005-2018_ICT_data_with\%2 0LDCs_rev27Nov2018.xls

Jian, W., Hsu, M., Sukati, H., Syed-abdul, S., \& Scholl, J. (2012). LabPush: A Pilot Study of Providing Remote Clinics with Laboratory Results via Short Message Service (SMS) in Swaziland, Africa. PLOS ONE, 7(9), 1-7. https://doi.org/10.1016/j.cmpb.2014.10.005

Johnston, M. J., King, D., Arora, S., Behar, N., Athanasiou, T., Sevdalis, N., \& Darzi, A. (2015). Smartphones let surgeons know WhatsApp: an analysis of communication in emergency surgical teams. The American Journal of Surgery, 209(1), 45-51. https://doi.org/10.1016/j.amjsurg.2014.08.030

Khanna, V., \& Sambandam, S. N. (2018). "WhatsApp" ening in orthopedic care: a concise report from a 300-bedded tertiary care teaching center. European Journal of Orthopaedic Surgery \& Traumatology, 5(25), 821-826. https://doi.org/10.1007/s00590-015-1600-y

Lester, R. T., Ritvo, P., Mills, E. J., Kariri, A., Karanja, S., Chung, M. H., ... \& Plummer, F. A. (2010). Effects of a mobile phone short message service on antiretroviral treatment adherence in Kenya (WelTel Kenya1): a randomised trial. The Lancet, 376(9755), 1838-1845. https://doi.org/10.1016/S0140-6736(10)61997-6

Lee, S., Cho, Y., \& Kim, S. (2017). Mapping mHealth (mobile health) and mobile penetrations in sub-Saharan Africa for strategic regional collaboration in mHealth scale-up: an application of exploratory spatial data analysis. Globalization and Health, 13(1), 63. https://doi.org/10.1186/s12992-017-0286-9

Little, A., Medhanyie, A., Yebyo, H., Spigt, M., Dinant, G. J., \& Blanco, R. (2013). Meeting community health worker needs for maternal health care service delivery using appropriate mobile technologies in Ethiopia. PloS One, 8(10), 1-14. https://doi.org/10.1371/journal.pone.0077563

Liu, J. X., \& Modrek, S. (2016). Evaluation of SMS reminder messages for altering treatment adherence and health seeking perceptions among malaria care-seekers in Nigeria. Health Policy and Planning, 31(10), 1374-1383. https://doi.org/10.1093/heapol/czw076

Malvey, D., \& Slovensky, D. J. (2014). mHealth: Transforming Health. New York, Springer. https://doi.org/10.1007/978-1-4899-7457-0

Mother, M., Shamseer, L., Clarke, M., Ghersi, D., Liberati, A., Petticrew, M., ... \& PRISMA-P Group (2015). Preferred reporting items for systematic review and meta-analysis protocols (PRISMA-P) 2015: elaboration and explanation. Systematic Review, 4(1). https://doi.org/10.1186/2046-4053-4-1

Mushamiri, I., Luo, C., Iiams-Hauser, C., \& Ben Amor, Y. (2015). Evaluation of the impact of a mobile health system on adherence to antenatal and postnatal care and prevention of mother-to-child transmission of HIV programs in Kenya. BMC Public Health, 15(1), 1-16. https://doi.org/10.1186/s12889-015-1358-5

Okedo-alex, I. N., Akamike, I. C., Ezeanosike, O. B., \& Uneke, C. J. (2019). Determinants of antenatal care utilisation in sub-Saharan Africa: a systematic review. BMJ Open, 9(10). e031890. https://doi.org/10.1136/bmjopen-2019-031890

Onwujekwe, O., Agwu, P., Orjiakor, C., Mckee, M., Hutchinson, E., Mbachu, C., ... \& Balabanova, D. (2019). Corruption in Anglophone West Africa health systems: a systematic review of its different variants and the factors that sustain them. Health Policy and Planning, 34(7), 529-543. https://doi.org/10.1093/heapol/czz070 
Otu, A., Ebenso, B., Okuzu, O., \& Osifo-Dawodu, E. (2016). Using a mHealth tutorial application to change knowledge and attitude of frontline health workers to Ebola virus disease in Nigeria: A before-and-after study. Human Resources for Health, 14(1), 1-9. https://doi.org/10.1186/s12960-016-0100-4

Pentapati, K. C., Smriti, K., \& Gadicherla, S. (2016). WhatsApp: A telemedicine platform for facilitating remote oral medicine consultation and improving clinical examinations - A commentary. Oral Surgery, Oral Medicine, Oral Pathology and Oral Radiology, 121(5), 1-3. https://doi.org/10.1016/j.oooo.2015.12.015

Pimmer, C. (2017). Mobile instant messaging for rural community health workers: a case from Malawi. Global Health Action, 10(1), 1-11. https://doi.org/10.1080/16549716.2017.1368236

Richards, R., Kinnersley, P., Brain, K., McCutchan, G., Staffurth, J., \& Wood, F. (2018). Use of Mobile Devices to Help Cancer Patients Meet Their Information Needs in Non-Inpatient Settings: Systematic Review. JMIR mHealth and uHealth, 6(12), 1-16. https://doi.org/10.2196/10026

Ronquillo, C., \& Currie, L. (2010). The digital divide: Trends in global mobile and broadband Internet access from 2000-2010. NI 2012: 11th International Congress on Nursing Informatics, June 23-27, 2012, Montreal, Canada. International Congress in Nursing Informatics (11th: 2012: Montrea, Quebec), 2012, 346.

Rokicki, S. (2017). Assessing the reach and effectiveness of mHealth: evidence from a reproductive health program for adolescent girls in Ghana. BMC Public Health, 17(1), 1-14. https://doi.org/10.1186/s12889-017-4939-7

Stanton, M. C., Mkwanda, S. Z., Debrah, A. Y., Batsa, L., Biritwum, N. K., Hoerauf, A., Cliffe, M, Best, A., Molineux, A. \& Kelly-Hope, L. A. (2015). Developing a community-led SMS reporting tool for the rapid assessment of lymphatic filariasis morbidity burden: Case studies from Malawi and Ghana. BMC Infectious Diseases, 15(1), 1-13. https://doi.org/10.1186/s12879-015-0946-4

Surka, S., Edirippulige, P., Steyn, K., Gaziano, T., Puoane, T., \& Levit, N. (2014) Evaluating the use of mobile phone technology to enhance cardiovascular disease screening by community health workers. International Journal of Medical Informatics, 83(9), 648-654. https://doi.org/10.1016/j.ijmedinf.2014.06.008

Uneke, C. J., Sombie, I., Keita, N., Lokossou, V., Johnson, E., \& Ongolo-Zogo, P. (2016). An assessment of maternal, newborn and child health implementation studies in Nigeria: implications for evidence informed policymaking and practice. Health Promotion Perspectives, 6(3), 119-127. https://doi.org/10.15171/hpp.2016.20

UN Foundation. (2009). mHealth for development: The opportunity of mobile technology for healthcare in the developing world. $\quad$ Retrieved 2nd $\quad$ October, 2018 from http:/unpan1.un.org/intradoc/groups/public/documents/unpan/unpan037268.pdf

Kop, V. D. M. L., Muhula, S., Nagide. P. I., Thabane. L., Gelmon. L., Awiti, P. O., .. \& Lester, R.T. (2018). Effect of an interactive text-messaging service on patient retention during the first year of HIV care in Kenya (WelTel Retain): an open-label, randomised parallel-group study. Lancet Public Health, 3(3), 1-121. https://doi.org/10.1016/S2468-2667(17)30239-6

Whitney, C. G. (2017). Measuring progress on preventing pneumonia deaths: are we there yet ? Global deworming: moving past albendazole and mebendazole. The Lancet Infectious Diseases, 17(11), 1100-1101. https://doi.org/10.1016/S1473-3099(17)30481-4

World Health Organization [WHO]. (1978). Declaration of Alma Ata: International Conference on Primary Health Care, Alma Ata, USSR, Geneva: World Health Organization. Retrieved from https://www.who.int/publications/almaata_declaration_en.pdf

World Health Organization [WHO]. (2012). Weekly epidemiological record: Pneumococcal vaccines (WHO position paper - 2012. No. 14, 87, 129-144).

World Health Organization [WHO]. (2018). mHealth: Use of appropriate digital technologies for public health. Seventy-First World Health Assembly Provisional agenda item 12.4

\section{Copyrights}

Copyright for this article is retained by the author(s), with first publication rights granted to the journal.

This is an open-access article distributed under the terms and conditions of the Creative Commons Attribution license (http://creativecommons.org/licenses/by/4.0/). 